University of Nebraska - Lincoln

DigitalCommons@University of Nebraska - Lincoln

USDA National Wildlife Research Center - Staff Publications
U.S. Department of Agriculture: Animal and Plant Health Inspection Service

2009

\title{
Feral swine damage and damage management in forested ecosystems
}

\author{
Tyler A. Campbell \\ USDA/APHIS/WS National Wildlife Research Center, tcampbell@eastfoundation.net \\ David B. Long \\ USDA/APHIS/WS National Wildlife Research Center
}

Follow this and additional works at: https://digitalcommons.unl.edu/icwdm_usdanwrc

Part of the Environmental Sciences Commons

Campbell, Tyler A. and Long, David B., "Feral swine damage and damage management in forested ecosystems" (2009). USDA National Wildlife Research Center - Staff Publications. 890.

https://digitalcommons.unl.edu/icwdm_usdanwrc/890

This Article is brought to you for free and open access by the U.S. Department of Agriculture: Animal and Plant Health Inspection Service at DigitalCommons@University of Nebraska - Lincoln. It has been accepted for inclusion in USDA National Wildlife Research Center - Staff Publications by an authorized administrator of DigitalCommons@University of Nebraska - Lincoln. 
Review

\title{
Feral swine damage and damage management in forested ecosystems
}

\author{
Tyler A. Campbell *, David B. Long \\ USDA, Animal and Plant Health Inspection Service, Wildlife Services, National Wildlife Research Center, \\ Texas AEM University-Kingsville, 700 University Boulevard, MSC 218, Kingsville, TX 78363, United States
}

\section{A R T I C L E I N F O}

\section{Article history:}

Received 19 December 2008

Received in revised form 17 March 2009

Accepted 19 March 2009

\section{Keywords:}

Control

Damage

Feral swine

Hog

Management

Pig

Sus scrofa

\begin{abstract}
A B S T R A C T
Invasive feral swine (Sus scrofa) cause deleterious impacts to ecosystem processes and functioning throughout their worldwide distribution, including forested ecosystems in the United States. Unfortunately, many feral swine damage management programs are conducted in a piecemeal fashion, are not adequately funded, and lack clearly stated or realistic objectives. This review paper identifies damage caused by feral swine to forest resources and presents techniques used to prevent and control feral swine damage. Concluding points related to planning a feral swine damage management program are: (1) the value of using a variety of techniques in an integrated fashion cannot be overstated; (2) there is value in using indices for both feral swine populations and their damage pre and post management activities; (3) innovative technologies will increasing be of value in the pursuit of feral swine damage reduction; and (4) though not appropriate in every situation, there is value in involving the public in feral swine damage management decisions and activities.
\end{abstract}

Published by Elsevier B.V.

\section{Contents}

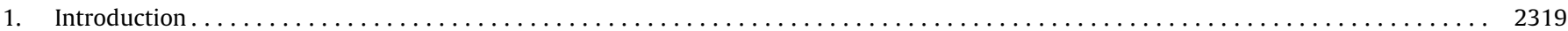

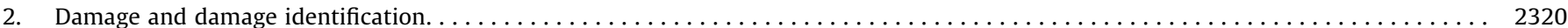

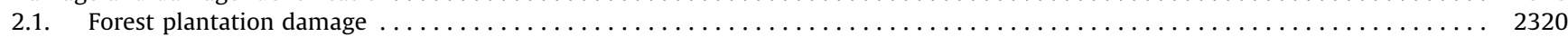

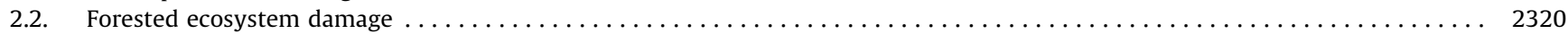

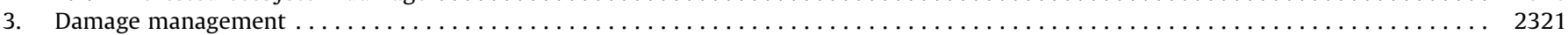

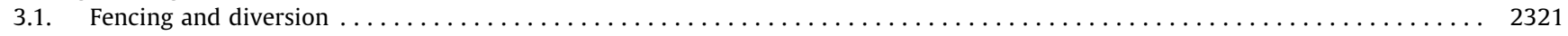

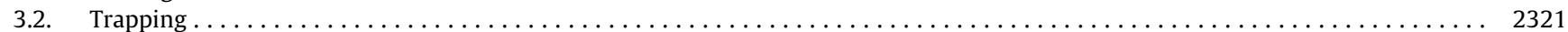

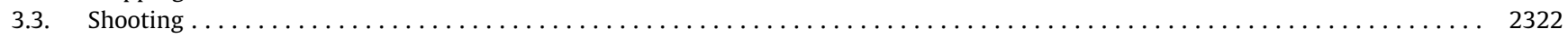

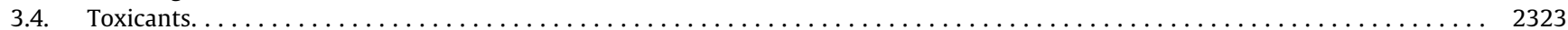

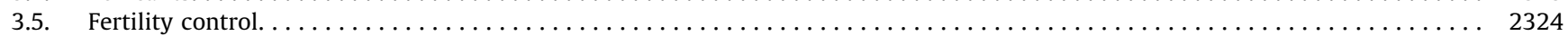

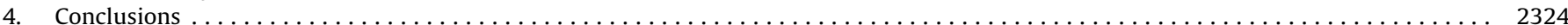

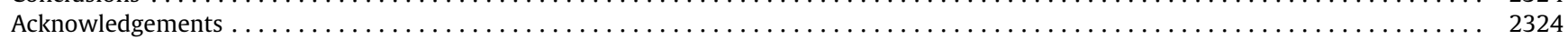

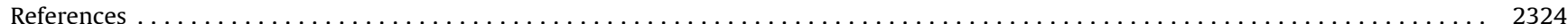

\section{Introduction}

Invasive feral swine (Sus scrofa) cause deleterious impacts to ecosystem processes and functioning throughout their worldwide distribution, including forested ecosystems in the United States. The geographic distribution and abundance of feral swine are increasing in the United States, where they cause an estimated $\$ 800$ million in losses each year (Pimentel et al., 2005). Forest and

\footnotetext{
* Corresponding author. Tel.: +1 361593 2426; fax: +1 3615934311

E-mail address: tyler.a.campbell@aphis.usda.gov (T.A. Campbell).
}

natural resource managers are beginning to recognize the significant threat these exotic ungulates pose to forested ecosystems (Seward et al., 2004) and are implementing feral swine damage management programs throughout their range. Unfortunately, many of these feral swine damage management programs are conducted in a piecemeal fashion, are not adequately funded, and lack clearly stated or realistic objectives. Under these situations, additional guidance is needed relating feral swine damage identification and management.

Several step-wise components will increase the likelihood of success of feral swine damage management programs (Hone, 1994; Conover, 2002; VerCauteren et al., 2005). First, the problem 
should be clearly identified, including the types and timing of damage being caused, and other biological, ecological, or sociological issues relating to the conflict. Second, an understanding of the ecology and life history of feral swine as they relate to the conflict should be obtained. Third, selection and implementation of the most effective, cost-efficient, humane, and socially acceptable management techniques using information gained through steps 1 and 2 to reduce the conflict, should take place. Lastly, an assessment of the reduction in damage over time, considering multiple factors such as costs and impact of management action on feral swine and non-target populations, should be performed to evaluate the effectiveness of the program. This brief review paper concentrates on the first and third of the abovementioned components in the context of a feral swine damage management in forested ecosystems. Specifically, damages caused by feral swine to forest resources are identified and techniques used to prevent and control feral swine damage are presented.

\section{Damage and damage identification}

In many areas feral swine are nocturnal and visible "signs", rather than direct observation, may have to be used to determine their presence (Taylor, 2003). These signs are relatively easy to distinguish from those left by native wildlife, and include tracks, trails, wallows, rooting, rubs, scat, and fence crossings (Barrett and Birmingham, 1994; Stevens, 1996; Taylor, 2003; Mapston, 2004). Feral swine tracks may be the most difficult type of sign to distinguish because of their resemblance to other ungulates, including white-tailed deer (Odocoileus virginianus), collared peccaries (Pecari tajacu), and domestic sheep and goats. Discriminating features of feral swine tracks are their blunt or rounded appearance at the tip of the toes; these form an overall square or round track shape (Stevens, 1996). Alternatively, whitetailed deer tracks are pointed and form a heart shape (Mapston, 2004). Both feral swine and white-tailed deer have 2 dew claws on each foot. However, collared peccaries lack outer dew claws on their hind feet and have a small track to body size ratio (Sowls, 1997). Given the comparatively smaller body size of collared peccaries (adult mean $=20 \mathrm{~kg}$; Hellgren and Bissonette, 2003), they generally have smaller tracks than feral swine.

Rooting (i.e., digging, grubbing, or plowing) at and below the soil surface is frequently observed when feral swine are present in an area, particularly during the winter and early spring when food is scarce (Dickson et al., 2001). Feral swine often use their snouts and keen olfaction to search for and use food resources within this nutrient-rich soil horizon (Conover, 2007). If soil conditions are favorable, feral swine can root to a depth $\leq 1 \mathrm{~m}$ (Mapston, 2004). Among agricultural producers, rooting by feral swine is the most widespread source of conflict (Stevens, 1996; Dickson et al., 2001). Feral swine rooting activities repeatedly damage farm equipment and vehicles, and injure livestock (Stevens, 1996; Taylor, 2003). Rooting by feral swine can decimate agricultural crops, pastures, and native plants, and can cause soil erosion (Barrett and Birmingham, 1994). In Australia, the frequency of occurrence of rooting has been used as an index of damage (Hone, 1995).

Equally identifiable are wallows created by feral swine. Wallows (i.e., depressions in mud, often filled with water) are created by the loafing, rolling, and rooting of feral swine (Stevens, 1996) and can be found in many low-lying, wet areas (Dickson et al., 2001). Feral swine, which lack sweat glands, will visit wallows >twice/day during the warm months to aid in their thermoregulation. However, wallows used habitually may produce contaminated riparian habitats (Stevens, 1996).

Feral swine rubs are frequently found in association with wallows in the warm months (Stevens, 1996) and are characterized by wet or dry mud-coated surfaces. Rubbing functions to remove excess or dried mud, hair, and ectoparasites. Feral swine commonly use trees, fallen logs, fence posts, utility poles, and rocks as substrates on which to rub, but have a preference for rubbing on creosote-treated posts (Stevens, 1996; Dickson et al., 2001). The height of the rub can be used to reveal the relative size of the feral swine that made it (Taylor, 2003). Scats, trails, and hair left at fence crossings are other sources of evidence used to determine the presence of feral swine.

\subsection{Forest plantation damage}

Feral swine can cause extensive damage to agricultural resources, including row crops and forest plantations. Feral swine damage within forest plantations primarily occurs within the seedling stage of development (Sweeney et al., 2003). Feral swine root up seedlings and consume roots of recently planted pines (Wakely, 1954; Conley et al., 1972; Lucas, 1977; Lipscomb, 1989) and hardwoods, such as cherrybark (Quercus pagoda) and swamp chestnut oak (Q. michauxii; Dickson et al., 2001), often resulting in regeneration failure. Groot Bruinderink and Hazebroek (1996) evaluated soil chemistry and forest regeneration within Scots pine (Pinus sylvestris) plantations used by feral swine in the Netherlands. They characterized rooting as (1) superficial litter rooting, (2) organic topsoil rooting, and (3) mineral soil rooting and compared rooted to non-rooted plots (Groot Bruinderink and Hazebroek, 1996). They found regeneration of oaks (Quercus spp.) and beech (Fagus sylvestris) were negatively related to rooting frequency and that no differences within other species, soil $\mathrm{pH}$, organic matter, and $\mathrm{N}$-contents occurred (Groot Bruinderink and Hazebroek, 1996).

\subsection{Forested ecosystem damage}

Feral swine may cause their greatest damage to environmentally sensitive areas and other natural ecosystems of conservation concern (Chavarria et al., 2007; Engeman et al., 2007b). Feral swine damage has been described for several, such as those occurring within rain forests. For example feral swine damage rain forests of the Pasoh Forest Reserve in Peninsular Malaysia, by reducing recruitment and growth of saplings (Ickes et al., 2001, 2003, 2005) and increasing the occurrence of the invasive shrub Clidemia hirta (Peters, 2001). Within a closed Hawaiian rain forest in the Kipahulu Valley of Maui, feral swine destroyed native forests by replacing the native flora with exotic species, such as strawberry guava (Psidium cattleianum), which they readily dispersed (Diong, 1982). In the Kilauea Forest Reserve of Hawaii, feral swine rooting prevented regeneration of young plants and modified forest structure and composition (Ralph and Maxwell, 1984). Similarly, within rain forests in Hawaii Volcanoes National Park, soil arthropods and biomass increased by 2 and 2.5 times, respectively, 7 years following feral swine removal (Vtorov, 1993). In north Queensland rain forests, feral swine reduced the number of seedlings and seedling survival (Mitchell et al., 2007). Clearly, feral swine damage to rain forest ecosystems can be great.

Feral swine also cause substantial damage within deciduous forests. Exhaustive work within the Great Smoky Mountains National Park and adjacent Tellico Wildlife Management Area in the Cherokee National Forest of Tennessee and North Carolina illustrate many of these ecosystem damages. For example, feral swine compete for acorns (Quercus spp.) and hickory nuts (Carya spp.) with native wildlife during poor or fair mast years (Henry and Conley, 1972); feral swine rooting activities in beech forest understories was such that they were not likely to recover (Bratton, 1975); feral swine reduced herbaceous and belowground forages within mesic communities such that recovery would take $\geq 3$ years (Howe et al., 1981); rooting by feral swine mixed the $A_{1}$ and $A_{2}$ 
soils horizons and reduced ground vegetative cover and leaf litter, which nearly extirpated northern short-tailed shrews (Blarina brevicauda) and southern red-backed voles (Clethrionomys gapperi) from intensively rooted areas (Singer et al., 1984); and feral swine rooting increased growth rates of American beech ( $F$. grandifolia) (Lacki and Lancia, 1986).

Feral swine damage is not limited to deciduous forests within the Appalachian Mountains. For example, feral swine caused extensive damage to recently planted hardwood seedlings within a wetland restoration area of South Carolina (Mayer et al., 2000). Additionally, feral swine actively search for and excavate cached acorns within burrows of small mammals in woodlands of Italy (Focardi et al., 2000). Similarly, within oak woodland ecosystems of California, feral swine reduced acorn survival and the availability of acorns for germination and consumption by native wildlife (Sweitzer and Van Vuren, 2002).

An underlying theme for most of the above investigations is that feral swine damage ecosystem processes often through their rooting, which alters soil properties and its nutritive properties. For example, rooting can accelerate leaching of calcium, copper, magnesium, phosphorus, and zinc from the soil (Singer et al., 1984), negatively impact soil building processes (Ford and Grace, 1998), accelerate rates of soil erosion (Sierra, 2001), and reduce soil magnesium, potassium, microbial activity, and the abundance of predatory soil arthropods (Mohr et al., 2005). Feral swine can also alter aquatic vertebrates and microbes within watersheds (Kaller and Kelso, 2006) and damage wetland habitats (Engeman et al., 2007a).

In addition to competing with native wildlife for limited resources, feral swine also cause direct mortality through predation. For example, feral swine have been implicated in local extinctions of the endangered Hutton's shearwater (Puffinus huttoni) in New Zealand (Cuthbert, 2002) and threaten local persistence of snake-necked turtles (Chelodina rugosa) in northern Australia (Fordham et al., 2006). Additionally, there are countless other species, such as shrub- and ground-nesting birds (Rollins and Carroll, 2001; Schaefer, 2004), in which predation by feral swine occurs with unknown effects to the prey populations. Feral swine may also function as prey and artificially increase the abundance of other predators. For example, work in the California Channel Islands suggests that feral swine have sustained a large breeding population of golden eagles (Aquila chrysaetos), which in turn have caused the near extirpation of 3 subspecies of island fox (Urocyon littoralis) through increased predation (Roemer et al., 2001, 2002; Knowlton et al., 2007).

\section{Damage management}

Similar to other invasive species in the United States, the most plausible means to manage feral swine damage in areas where they do not occur is to prevent their arrival and establishment. This, however, is no simple feat and has been met with limited success. For example, Gipson et al. (1998) described recently established (since 1988) feral swine populations in Colorado, Kansas, Missouri, Kentucky, Illinois, Indiana, Ohio, and West Virginia. Today, feral swine populations have continued their northern expansion into Oregon, Nebraska, Iowa, Pennsylvania, Minnesota, Wisconsin, and New Jersey. By all indication, the expansion of feral swine populations in the United States will continue without regulations aimed at curbing clandestine and accidental releases, the enforcement of existing and new regulations, and a general increase in public understanding and awareness of the conflict (e.g., see Rollins et al., 2007). Therefore, many natural resource agencies, landowners, and managers will increasingly be implementing feral swine damage management programs (e.g., see State of Hawaii, 2007). With Australia's long history of feral swine damage management as evidence, Izac and O'Brien (1991) recommend that first and foremost these programs should be flexible. The techniques used by these programs, and described below, are both conventional and innovative. Legal, social, and economic issues related to these damage management techniques should be explored before implementation (Conover, 2002). Practitioners are encouraged to peruse Littauer (1993), Mapston (2004) and Hartin (2006) for more comprehensive "how to" presentations for many of these techniques and contact local USDA APHIS Wildlife Services or state wildlife agency personnel for technical assistance. Additionally, the advantages and disadvantages for many of the techniques mentioned have been summarized (Table 1).

\subsection{Fencing and diversion}

Comparative studies among fence designs to either exclude feral swine or inhibit their movements into sensitive forested areas are few. In a captive setting in Australia no incursions by feral swine through fine-mesh hog paneling were observed and when electricity was applied to the other 7 fence designs, incursions were reduced (Hone and Atkinson, 1983). Additionally, in a captive setting in southern Texas, electrified polywire reduced incursions for 1, 2, and 3 stranded fences, with 2 and 3 stranded fences demonstrating 50 and $40 \%$ fewer incursions than the 1-stranded fence, respectively (Reidy et al., 2008). These data were further validated in rangeland and cropland settings (Reidy et al., 2008). Nevertheless, both electrified and non-electrified fencing are regularly used as part of feral swine damage management programs. For example, electric fencing was used to control feral swine movement to lambing areas in New South Wales, Australia (Pavlov et al., 1981); to preclude future immigration following feral swine removal in Annadel State Park, California (Barrett et al., 1988); to partition feral swine management units in Haleakala National Park, Hawaii (Anderson and Stone, 1993); to augment other feral swine control measures in Hawaii Volcanoes National Park (Katahira et al., 1993); to exclude feral swine in lamb predation experiments in Australia Choquenot et al. (1997); to monitor and assess regeneration dynamics in the Netherlands (Kuiters and Slim, 2002); and to create feral swine management units in California Wilcox et al. (2004). Practitioners should consider the cost of fence construction and maintenance costs before using this technique (VerCauteren et al., 2005).

Using bait to divert feral swine away from seasonally available resources has only recently received attention in the literature. For example, in southeastern France, less damage was found to vineyards where large quantities of corn were distributed in the adjacent woods to divert feral swine from grape production areas (Calenge et al., 2004). However, bait (e.g., corn, fruits, potatoes, and manufactured pellets) dispersed adjacent to cropland was ineffective at reducing feral swine damage in Switzerland (Geisser and Reyer, 2004). Although diversion is an attractive method for reducing feral swine damage, practitioners should consider its cost, impact on feral swine population sizes, and appropriateness as only a short-term solution (Conover, 2002). An additional form of diversion, which might be considered habitat modification, has been used in the Netherlands. Here, a 50 m wide motorway wildlife overpass was constructed to connect suitable habitats and reduce wildlife-vehicle collisions. These wildlife overpasses were used heavily by feral swine (8.3 incursions/night; Van Wieren and Worm, 2001).

\subsection{Trapping}

Feral swine traps come in an assortment of configurations from manufactured traps to homemade varieties. Live traps, such as 
Table 1

Advantages and disadvantages ${ }^{\mathrm{a}}$ (excluding social and legal considerations) of techniques available to manage feral swine damage in the United States.

\begin{tabular}{|c|c|c|}
\hline Technique & Advantages & Disadvantages \\
\hline Fencing & $\begin{array}{l}\text { Effective when well constructed and maintained } \\
\text { Non-lethal } \\
\text { May be used to help define management units }\end{array}$ & $\begin{array}{l}\text { Resources may be damaged in adjacent areas } \\
\text { Expensive to build and maintain }\end{array}$ \\
\hline Cage or corral traps & $\begin{array}{l}\text { Multiple animals can be obtained at once } \\
\text { May be non-lethal } \\
\text { Can be used where snare anchor points are limited } \\
\text { Non-target animals may be released unharmed } \\
\text { Can be used in residential areas } \\
\text { May catch animals that have developed avoidance behavior to other methods }\end{array}$ & $\begin{array}{l}\text { Higher cost where accessibility is limited } \\
\text { Less effective when natural foods are abundant } \\
\text { Some animals become shy of traps } \\
\text { Must be checked regularly } \\
\text { May be cumbersome to move and transport }\end{array}$ \\
\hline Snares & $\begin{array}{l}\text { Least expensive technique } \\
\text { Effective at low population densities } \\
\text { May catch wary animals for which other techniques fail }\end{array}$ & $\begin{array}{l}\text { Non-target animals may be susceptible } \\
\text { Only one animal can be obtained at once } \\
\text { Large animals sometimes break snares } \\
\text { Cannot be used where snare anchor points are limited }\end{array}$ \\
\hline Aerial shooting & $\begin{array}{l}\text { Highly selective in that only target animals are removed } \\
\text { Damage is reduced immediately } \\
\text { Rapid removal of many animals } \\
\text { Effective for removal of remnant animals following other techniques }\end{array}$ & $\begin{array}{l}\text { Expensive } \\
\text { Less effective where animals have significant cover } \\
\text { Can be hazardous, particularly in rugged topography } \\
\text { Weather conditions can cause scheduling conflicts }\end{array}$ \\
\hline Ground shooting & $\begin{array}{l}\text { May be conducted during nocturnal hours } \\
\text { Highly selective } \\
\text { May remove trap wary animals } \\
\text { Complements other techniques } \\
\text { May provide public access to hunting resources }\end{array}$ & $\begin{array}{l}\text { Can be time and labor intensive } \\
\text { Low success rates where population densities are low } \\
\text { May be limited by access }\end{array}$ \\
\hline Hunting with dogs & $\begin{array}{l}\text { Effective for target animals that have evaded other techniques } \\
\text { Many animals may be removed in a short time } \\
\text { Effective where population densities are high } \\
\text { Can be used in residential areas } \\
\text { May provide public access to hunting resources }\end{array}$ & $\begin{array}{l}\text { Dogs may be injured or killed when baying large animals } \\
\text { Training dogs is labor intensive } \\
\text { Insufficiently trained dogs may take non-target animals } \\
\text { Limited by heat stress to dogs during the warm months }\end{array}$ \\
\hline
\end{tabular}

a Modified from State of Hawaii (2007) and Littauer (1993).

cage (or box) and corral traps, are typically baited with corn and other grains in either a fresh or fermented condition (e.g., see Matschke, 1962; Belden and Frankenberger, 1977; Foreyt and Glazener, 1979), though carrion has also been used (Littauer, 1993). However, bait consumption by non-target animals is often high at trap sites (Hartin, 2006), thereby increasing management costs. This has led researchers to evaluate various attractants or lures for feral swine to be used as part of a management program. In Australia, researchers found no differences among creosote, fish stock, meatmeal, molasses, and vanilla attractants for captive, wild-caught feral swine (Elsworth et al., 2004). Similar findings have been reported for feral swine in the Great Smoky Mountains National Park of Tennessee and North Carolina (Peine and Farmer, 1990). However, among a suite of 11 candidate flavors, strawberry was found to be a specific attractant for feral swine in southern Texas (Campbell and Long, 2008). Using sows in estrus as lures to aid feral swine trapping efforts has also been evaluated in Australia with mixed results (Choquenot et al., 1993; Mcllroy and Gifford, 2005). At present, universal feral swine lures to augment grain bait in trapping efforts have not been identified.

The live capture of feral swine has been practiced for decades (Matschke, 1962; Belden and Frankenberger, 1977) and modifications to traps have been suggested (Foreyt and Glazener, 1979; Sweitzer et al., 1997), in many cases evolving with management programs (Peine and Farmer, 1990). Generally, live traps consist of welded or otherwise secure heavy gauge paneling of fine mesh (e.g., $10 \mathrm{~cm} \times 10 \mathrm{~cm}$, Sweitzer et al., 1997; $50 \mathrm{~mm} \times 50 \mathrm{~mm}$, Caley, 1994) with steel tubing or t-posts as frames. Live traps may be completely enclosed in a cage formation (Sterner and Barrett, 1991; Katahira et al., 1993; Fournier et al., 1995; Wyckoff et al., 2006) or open in a corral formation (Choquenot et al., 1993; Caley, 1994; Saunders et al., 1993). A key component of live traps is their gate and top-hinged swing gates or "root doors" (Belden and Frankenberger, 1977; Sterner and Barrett, 1991; Choquenot et al., 1993; Saunders et al., 1993; Sweitzer et al., 1997), drop gates
(Foreyt and Glazener, 1979; Caley, 1994; Fournier et al., 1995), and side-hinged spring gates (Sweitzer et al., 1997) which have been used with success. Also, camouflaging traps with natural vegetation may increase trapping success (Katahira et al., 1993). The effectiveness of live traps may vary seasonally (Barrett et al., 1988; Saunders et al., 1993; Caley, 1994; Wyckoff et al., 2006) and sex biases may occur (Choquenot et al., 1993). In several instances, live traps have been determined more effective than other techniques (Sterner and Barrett, 1991).

Despite their high use in feral swine damage management programs in some areas, snares are the least studied damage control technique available (Littauer, 1993; Mapston, 1999). This may be because Australian colleagues who are at the forefront of feral swine damage control research have not found the technique to be socially acceptable (Cowled and Lapidge, 2004). Snare traps are a lethal technique and consist of a steel cable formed into a loop and anchored to a secure object or drag. Feral swine are captured when the loop cinches around the animal as it travels through a confined area, such as holes under or within barbed wire fences (Littauer, 1993). Snare traps have been used to eradicate feral swine from the Kipahulu Valley within the Haleakala National Park, Hawaii (Anderson and Stone, 1993) and were more efficient than ground hunting over a 15-year period in Hakalau National Wildlife Refuge, Hawaii (Hess et al., 2006).

\subsection{Shooting}

In many situations, public hunting alone has been found to be insufficient at reducing feral swine damage because only small numbers of animals are removed on a sustained basis (Barrett and Pine, 1980; Updike and Waithman, 1996; Zivin et al., 2000). For example, public hunting did not control feral swine populations in France (Baubet et al., 2004) or reduce agricultural damage in central Italy (Mazzoni della Stella et al., 1995). Additionally, public hunting was less efficient than snaring in a tropical montane 
rainforest in Hawaii (Hess et al., 2006) and trapping on Santa Cruz Island, California (Sterner and Barrett, 1991). However, in Switzerland, public hunting (compared to diversion feeding and fencing) reduced damage caused by feral swine (Geisser and Reyer, 2004), and in Florida, feral swine damage to seepage slopes were 2 times greater in unhunted areas compared to hunted areas (Engeman et al., 2007b). Furthermore, there is evidence that the demand for sport hunting opportunities for feral swine is increasing across portions of their range (Rollins, 1993). Consequently, there is value in including sportspersons who are interested in feral swine as a harvestable resource in management programs (Mansfield, 1978; Tisdell, 1980; Seward et al., 2004), perhaps employing a cooperative approach (Robinson et al., 2005). However, caution should be taken when considering the sole reliance on public hunting to control damage caused by this invasive species, as this approach has been largely unsuccessful.

Controlled shooting by skilled sharpshooters is another technique available to reduce feral swine damage in some regions and scenarios. Controlled shooting is often only implemented as part of an integrated management program by agency biologists or other trained personnel, and therefore may not be an option in some situations. This technique may include the use of bait stations, spotlights (Mapston, 2004), night vision equipment (Adams et al., 2006), and noise suppression devices (with special permits, as appropriate). On Santiago Island, Galapagos, Ecuador, controlled shooting was moderately effective at controlling feral swine populations (Coblentz and Baber, 1987). The advantages of the technique are that many animals can be removed over a short duration and the technique is selective because it targets the culprits causing the damage (Adams et al., 2006).

Using dogs to locate, bay, and hold feral swine for subsequent removal can be effective at reducing damage when well-trained dogs and skilled hunters are employed (Mapston, 2004) and is popular in the southern United States as a recreational activity (Dickson et al., 2001). In Annadel State Park, California, hunting with dogs was successful in all seasons (Barrett et al., 1988) and at Hawaii Volcanoes National Park, feral swine were eradicated primarily through the use of hunting dogs (Katahira et al., 1993). However, as with many of the other techniques mentioned, hunting feral swine with dogs is best used in conjunction with other control techniques in an integrated management program. For example, hunting with dogs was effective at removing residual feral swine following reduction with other methods in Australia (Mcllroy and Saillard, 1989; Caley and Ottley, 1995) and on Santiago Island, Galapagos, Ecuador (Cruz et al., 2005).

There has been considerable interest in the scientific literature aimed at whether or not dog hunting functions to alter movements or disperse feral swine. In the Namadgi National Park, Australian Capital Territory, hunting with dogs did not cause feral swine to disperse (Mcllroy and Saillard, 1989). However, in southern and northeastern France, dog hunting caused feral swine to maintain larger home ranges, but similar core areas (Calenge et al., 2002). Behavioral plasticity was also demonstrated in Lower Saxony, Germany where $60 \%$ of feral swine remained within their home ranges following hunting with dogs and $40 \%$ moved $\leq 6 \mathrm{~km}$, but returned within 6 weeks (Sodeikat and Pohlmeyer, 2003). Others determined dog hunting to be the primary disturbance of feral swine in southern France which caused increased daily movements and larger home range sizes (Maillard and Fournier, 1995).

In some locales, shooting feral swine from either a fixed wing aircraft or helicopter is a legal and effective technique for controlling damage. As with controlled ground shooting, aerial shooting should be implemented by agency biologists or other trained personnel and may require special licenses or permits (Mapston, 2004). Though comparatively expensive, aerial shooting reduces damage from feral swine quickly and is selective (Littauer,
1993; Saunders, 1993). However, the use of this technique is limited to areas without dense vegetative cover or rough terrain (Hone, 1983; Mapston, 2004), which precludes its use in many forested ecosystems.

Research involving the effectiveness of aerial shooting at reducing feral swine damage and the influence of the technique on feral swine movements are lacking from the United States. However, colleagues in Australia found removal rates of feral swine to range from 65 to $97 \%$ using aerial shooting (Hone, 1983; Saunders and Bryant, 1988; Hone, 1990; Saunders, 1993), with success depending upon the availability of refuge habitat, population density, and habituation to aerial shooting by feral swine (Choquenot et al., 1999). Nonetheless, in western New South Wales, 1 year following an initial aerial shooting campaign, populations had recovered to $77 \%$ of the their original levels, suggesting that annual campaigns may be needed to keep damage within acceptable limits due to increased immigration and other factors (Saunders, 1993). In both western and northwestern New South Wales, feral swine did not alter their movements in response to aerial shooting (Saunders and Bryant, 1988; Dexter, 1996).

Another innovative technique that has been proposed to reduce feral swine damage involves placing radio transmitters on trapped animals and tracking them following release to reveal the location of other feral swine in the area (Littauer, 1993; Mcllroy, 1995; Richardson et al., 1997). This method has been coined the Judas pig technique and exploits the social attributes of feral swine. On large tracts of land involving discontinuous populations, Judas pigs may provide information on where to target feral swine control efforts (Mcllroy and Gifford, 2005). For example, in the Namadgi National Park, Australian Capital Territory, the Judas pig technique has been used successfully to determine where to distribute toxic baits (Mcllroy and Gifford, 1997). Similarly, the technique was found useful at reducing time spent locating feral swine when integrated with other methods, such as ground and aerial shooting, trapping, and hunting with dogs in Santa Clara County, California (Wilcox et al., 2004). Sows trapped locally have been found to make superlative Judas pigs (Mcllroy and Gifford, 1997; Wilcox et al., 2004).

\subsection{Toxicants}

There are no toxicants registered by the United States Environmental Protection Agency for use on feral swine in the United States. One critical step for registering a feral swine toxicant (or other orally delivered pharmaceuticals, such as vaccines) is the development a feral swine-specific oral delivery vehicle or bait. In the United States, investigations involving feral swine baits are scarce. On Ossabaw Island, Georgia, researchers found oral delivery of pharmaceuticals to feral swine was feasible (Fletcher et al., 1990) and baits could be used to deliver pharmaceuticals to feral swine (Kavanaugh and Linhart, 2000). These studies found high removal and consumption of baits by feral swine and non-target animals, such as raccoons (Procyon lotor; Fletcher et al., 1990; Kavanaugh and Linhart, 2000). In southern Texas, researchers found high visitation by feral swine, raccoons, collared peccaries, coyotes (Canis latrans), white-tailed deer (Odocoileus virginianus), striped skunks (Mephitis mephitis), and opossums (Didelphis virginiana) to manufactured baits (Campbell et al., 2006; Campbell and Long, 2007). However, these manufactured baits were nearspecific to feral swine in Australia (Cowled et al., 2006a,b), which maintains fewer omnivorous non-target mammals. The pursuit of a feral swine-specific oral pharmaceutical delivery system in the United States will continue.

In Australia, early toxicant research was conducted in captive settings and focused on dyed grain as a delivery vehicle (Hone et al., 1985; Kleba et al., 1985), the sensitivity, intake, and toxicity 
of sodium fluoroacetate (compound 1080; Mcllroy, 1983; O’Brien, 1988; O'Brien et al., 1988) and warfarin (Hone and Kleba, 1984; O'Brien and Lukins, 1990), the influence of anti-emetics when delivered with compound 1080 (Rathore, 1985; O'Brien et al., 1986), and model parameterization (Hone, 1992). This research was subsequently augmented by studies on free-ranging feral swine, including bait uptake and consumption studies (Mcllroy et al., 1993; Choquenot and Lukins, 1996), compound 1080 intake (O’Brien and Lukins, 1988), risk assessments to non-target animals (Mcllroy, 1992; Twigg et al., 2005a), the effectiveness of ground baiting campaigns with compound 1080 (Hone and Pedersen, 1980; Hone, 1983; Twigg et al., 2005b; Cowled et al., 2006a; Twigg et al., 2006, 2007) and warfarin (Mcilroy et al., 1989; Mcllroy and Saillard, 1989; Saunders et al., 1990; Choquenot et al., 1990), and the effectiveness of aerial baiting campaigns (Mitchell, 1998; Fleming et al., 2000). Compound 1080 and warfarin have also been used to eradicate feral swine from Santiago Island in the Galápagos archipelago, Ecuador (Coblentz and Baber, 1987; Cruz et al., 2005). Additional toxicants are being identified and evaluated that exploit physiologic vulnerabilities of feral swine (Cowled et al., 2008).

The exhaustive research into toxicants and their efficacious application in Australia and within insular populations has been fueled largely by the extensive damage caused by invasive feral swine and the corresponding acceptance of the technique by the public. Taken as a whole, the United States citizenry has not yet reached this point and, at present, finds the use of toxicants in feral swine damage management socially unacceptable. If trends in distribution, abundance, and damage continue in the United States for this invasive species, it is conceivable that toxicants may be developed and registered for use on feral swine populations in the future, following Australia's lead (Seward et al., 2004).

\subsection{Fertility control}

There is no fertility control agent registered by the United States Environmental Protection Agency for use on feral swine in the United States. However, work by USDA APHIS Wildlife Services' National Wildlife Research Center scientists and their colleagues has identified a single injection gonadotropin-releasing hormone $(\mathrm{GnRH})$ vaccine as effective in controlling fertility of feral swine (Killian et al., 2006) and found favorable results for a second generation recombinant $\mathrm{GnRH}$ vaccine that may be small enough to be effective when administered orally (Miller et al., 2006). More research on these and other fertility control agents is needed before science-based prescriptions can be formulated and products can be registered and made available (Fagerstone et al., 2006).

\section{Conclusions}

In closing, when planning a feral swine damage management program it may be beneficial to consider several points. First, as illustrated by numerous examples throughout this review paper, the value of using a variety of techniques in an integrated fashion cannot be overstated. This is particularly true for feral swine because they often become "educated" and learn to evade capture or removal when using one technique exclusively (Choquenot et al., 1999). Second, there is value in using indices for both feral swine populations and their damage pre and post management activities (e.g., see Engeman et al., 2007b). These data may then be used to monitor the progress of programs and make adjustments, as needed. Many of the feral swine damage management programs currently implemented in the United States (more so on private land) lack this feedback mechanism due to the added costs. However, as feral swine damage management programs continue to emerge in response to burgeoning populations, the public will increasingly demand that measures, in addition to the number of animals removed, are used to assess program effectiveness. Furthermore, these information may be of value for others considering implementing management programs. Third, innovative technologies, including geographic (Lavoie et al., 2007) and genetic (DeYoung, 2008) tools, will increasing be of value in the pursuit of feral swine damage reduction. Practitioners are encouraged to incorporate these tools into their management programs to the fullest extent of their skill and expertise. Lastly, though not appropriate in every situation, there is value in involving the public in feral swine damage management decisions and activities, including efforts to increase public awareness of feral swine damage (Rollins et al., 2007). In the United States, not until society as a whole becomes more knowledgeable of the many conflicts associated with invasive feral swine will we get serious about resolving this complex problem.

\section{Acknowledgements}

We thank Johanna Delgado-Acevedo for comments to the manuscript. Funding was provided by the USDA APHIS Wildlife Services program.

\section{References}

Adams, C.E., Lindsey, K.J., Ash, S.J., 2006. Urban Wildlife Management. Taylor and Francis Group, Boca Raton, FL, USA.

Anderson, S.J., Stone, C.P., 1993. Snaring to control feral pigs Sus scrofa in a remote Hawaiian rain forest. Biological Conservation 63, 195-201.

Barrett, R.H., Birmingham, G.H., 1994. Wild pigs. In: Hygnstrom, S.E., Timm, R.M (Eds.), Prevention and Control of Wildlife Damage, vol. 2. University of Nebraska-Lincoln Press, Lincoln, NE, USA, pp. D-65-D-70.

Barrett, R.H., Goatcher, B.L., Gogan, P.J., Fitzhugh, E.L., 1988. Removing feral pigs from Annadel State Park. Transactions of the Western Section of The Wildlife Society 24, 47-52.

Barrett, R.H., Pine, D.S., 1980. History and status of wild pigs, Sus scrofa, in San Benito County, California. California Fish and Game 67, 105-117.

Baubet, É., Servanty, S., Brandt, S., Toïgo, C., Klein, F., 2004. Améliorer la connaissance du fonctionnement démographique des populations de sangliers: vers une meilleure gestion de l'espèce Sus scrofa. Office National de la Chasse et de la Faune Sauvage, Paris, France (in French).

Belden, R.C., Frankenberger, W.B., 1977. A portable root-door hog trap. In: Proceedings of the Southeastern Association of Fish and Wildlife Agencies, 31. pp. 123 125.

Bratton, S.P., 1975. The effect of the European wild boar, Sus scrofa, on Gray Beech Forest in the Great Smoky Mountains. Ecology 56, 1356-1366.

Calenge, C., Maillard, D., Fournier, P., Fouque, C., 2004. Efficiency of spreading maize in the garrigues to reduce wild boar (Sus scrofa) damage to Mediterranean vineyards. European Journal of Wildlife Research 50, 112-120.

Calenge, C., Maillard, D., Vassant, J., Brandt, S., 2002. Summer and hunting season home ranges of wild boar (Sus scrofa) in two habitats in France. Game Wildlife Science 19, 281-301.

Caley, P., 1994. Factors affecting the success rate of traps for catching feral pigs in a tropical habitat. Wildlife Research 21, 287-292.

Caley, P., Ottley, B., 1995. The effectiveness of hunting dogs for removing feral pigs (Sus scrofa). Wildlife Research 22, 147-154.

Campbell, T.A., Lapidge, S.J., Long, D.B., 2006. Using baits to deliver pharmaceuticals to feral swine in southern Texas. Wildlife Society Bulletin 34,1184-1189.

Campbell, T.A., Long, D.B., 2008. Mammalian visitation to candidate feral swine attractants. Journal of Wildlife Management 71, 305-309.

Campbell, T.A., Long, D.B., 2007. Species-specific visitation and removal of baits for delivery of pharmaceuticals to feral swine. Journal of Wildlife Diseases 43, 485491.

Chavarria, P.M., Lopez, R.R., Bowser, G., Silvy, N.J., 2007. A landscape-level survey of feral hog impacts to natural resources of the Big Thicket National Preserve. Human-Wildlife Conflicts 1, 199-204.

Choquenot, D., Hone, J., Saunders, G., 1999. Using aspects of predator-prey theory to evaluate helicopter shooting for feral pig control. Wildlife Research 26, 251 261.

Choquenot, D., Kay, B., Lukins, B., 1990. An evaluation of warfarin for the control of feral pigs. Journal of Wildlife Management 54, 353-359.

Choquenot, D., Kilgour, R.J., Lukins, B.S., 1993. An evaluation of feral pig trapping. Wildlife Research 20, 15-22.

Choquenot, D., Lukins, B., 1996. Effect of pasture availability on bait uptake by feral pigs in Australia's semi-arid rangelands. Wildlife Research 23, 421-428.

Choquenot, D., Lukins, B., Curran, G., 1997. Assessing lamb predation by feral pigs in Australia's semi-arid rangelands. Journal of Applied Ecology 34, 1445-1454.

Coblentz, B.E., Baber, D.W., 1987. Biology and control of feral pigs on Isla Santiago, Galápagos, Ecuador. Journal of Applied Ecology 24, 403-418. 
Conley, R.H., Henry, V.G., Matschke G.H., 1972. Final Report for the European hog research project W-34. Tennessee Game and Fish Commission, Nashville, TN, USA.

Conover, M.R., 2002. Resolving Human-wildlife Conflicts the Science of Wildlife Damage Management. Lewis Publishers, Boca Raton, FL, USA.

Conover, M.R., 2007. Predator-prey Dynamics the Role of Olfaction. CRC Press, Boca Raton, FL, USA.

Cowled, B.D., Elsworth, P., Lapidge, S.J., 2008. Additional toxins for feral pig (Sus scrofa) control: identifying and testing Achilles' heels. Wildlife Research 35 , 651-662.

Cowled, B.D., Gifford, E., Smith, M., Staples, L., Lapidge, S.J., 2006a. Efficacy of manufactured PIGOUT ${ }^{\mathbb{B}}$ baits for localized control of feral pigs in the semiarid Queensland rangelands. Wildlife Research 33, 427-437.

Cowled, B.D., Lapidge S.J., 2004. A project that investigates current options for managing feral pigs in Australia and assesses the need for the development of more effective and humane techniques and strategies-Stage 2 Report. Pest Animal Control Cooperative Research Centre, Canberra, Australia.

Cowled, B.D., Lapidge, S.J., Smith, M., Staples, L., 2006b. Attractiveness of a novel omnivore bait, PIGOUT ${ }^{\mathbb{R}}$, to feral pigs (Sus scrofa) and assessment of risks of bait uptake by non-target species. Wildlife Research 33, 651-660.

Cruz, F., Donlan, C.J., Campbell, K., Carrion, V., 2005. Conservation action in the Galápagos: feral pig (Sus scrofa) eradication from Santiago Island. Biological Conservation 121, 473-478.

Cuthbert, R., 2002. The role of introduced mammals and inverse density-dependent predation in the conservation of Hutton's shearwater. Biological Conservation $108,69-78$.

Dexter, N., 1996. The effect of an intensive shooting exercise from a helicopter on the behaviour of surviving feral pigs. Wildlife Research 23, 435-441.

DeYoung, R.W., 2008. Genetics and applied management: using genetic methods to solve emerging wildlife management problems. In: Fulbright, T.E., Hewitt, D.G. (Eds.), Wildlife Science Linking Ecological Theory and Management Applications. CRC Press, Boca Raton, FL, USA, pp. 317-336.

Dickson, J.G., Mayer, J.J., Dickson, J.D., 2001. Wild hogs. In: Dickson, J.G. (Ed.), Wildlife of Southern Forests: Habitat and Management. Hancock House Publishers, Blaine, WA, USA, pp. 191-208.

Diong, C.H., 1982. Population biology and management of the feral pig (Sus scrofa) in Kipahulu Valley, Maui. Dissertation. University of Hawaii, Manoa, Hawaii, USA.

Elsworth, P.G., Mitchell, J.L., Parker, R.W., 2004. Evaluation of attractants and toxins for improved target specificity in the control of feral pigs. Queensland Government, Natural Resources and Mines, Robert Wicks Pest Animal Research Centre, Inglewood, Queensland, Australia.

Engeman, R.M., Constantin, B.U., Shwiff, S.A., Smith, H.T., Woolard, J., Allen, J. Dunlap, J., 2007a. Adaptive and economic management methods for fera hog control in Florida. Human-Wildlife Conflicts 1, 178-185.

Engeman, R.M., Stevens, A., Allen, J., Dunlap, J., Daniel, M., Teague, D., Constantin, B. 2007b. Feral swine management for conservation of an imperiled wetland habitat: Florida's vanishing seepage slopes. Biological Conservation 134 440-446.

Fagerstone, K.A., Miller, L.A., Bynum, K.S., Eisemann, J.D., Yoder, C., 2006. When, where and for what species will contraception be a useful management approach? In: Proceedings of the Vertebrate Pest Conference, 22. pp. 45-54.

Fleming, P.J.S., Choquenot, D., Mason, R.J., 2000. Aerial baiting of feral pigs (Sus scrofa) for the control of exotic disease in the semi-arid rangelands of New South Wales. Wildlife Research 27, 531-537.

Fletcher, W.O., Creekmore, T.E., Smith, M.S., Nettles, V.F., 1990. A field trial to determine the feasibility of delivering oral vaccines to wild swine. Journal of Wildlife Diseases 26, 502-510.

Focardi, S., Capizzi, D., Monetti, D., 2000. Competition for acorns among wild boar (Sus scrofa) and small mammals in a Mediterranean woodland. Journal of Zoology, London 250, 329-334.

Ford, M.A., Grace, J.B., 1998. Effects of vertebrate herbivores on soil processes, plan biomass, litter accumulation and soil elevation changes in a coastal marsh. Journal of Ecology 86, 974-982.

Fordham, D., Georges, A., Corey, B., Brook, B.W., 2006. Feral pig predation threaten the indigenous harvest and local persistence of snake-necked turtles in northern Australia. Biological Conservation 133, 379-388.

Foreyt, W.J., Glazener, W.C., 1979. A modified box trap for capturing feral hogs and white-tailed deer. Southwestern Naturalist 24, 377-380.

Fournier, P., Maillard, D., Fournier-Chambrillon, C., 1995. Use of spotlights for capturing wild boar (Sus scrofa). IBEX Journal of Mountain Ecology 3, 131 133

Geisser, H., Reyer, H., 2004. Efficacy of hunting, feeding, and fencing to reduce crop damage by wild boars. Journal of Wildlife Management 68, 939-946.

Gipson, P.S., Hlavachick, B., Berger, T., 1998. Range expansion by wild hogs across the central United States. Wildlife Society Bulletin 26, 279-286.

Groot Bruinderink, G.W.T.A., Hazebroek, E., 1996. Wild boar (Sus scrofa scrofa) rooting and forest regeneration on podzolic soils in the Netherlands. Fores Ecology and Management 88, 71-80.

Hartin, R.E., 2006. Feral hogs: status and distribution in Missouri. Thesis. University of Missouri-Columbia, Columbia, MO, USA

Hellgren, E.C., Bissonette, J.A., 2003. Collared peccary. In: Feldhamer, G.A., Thompson, B.C., Chapman, J.A. (Eds.), Wild Mammals of North America: Biology, Management, and Conservation. second edition. John Hopkins University Press, Baltimore, MD, USA, pp. 867-876.

Henry, V.G., Conley, R.H., 1972. Fall foods of European wild hogs in the southern Appalachians. Journal of Wildlife Management 36, 854-860.
Hess, S.C., Jeffrey, J.J., Ball, D.L., Babich, L., 2006. Efficacy of feral pig removals at Hakalau Forest National Wildlife Refuge, Hawaii. Transactions of the Western Section of The Wildlife Society 42, 53-67.

Hone, J., 1983. A short-term evaluation of feral pig eradication at Willandria in western New South Wales. Australian Wildlife Research 10, 269-275.

Hone, J., 1990. Predator-prey theory and feral pig control, with emphasis on evaluation of shooting from a helicopter. Australian Wildlife Research 17, 123-130.

Hone, J., 1992. Modelling of poisoning for vertebrate pest control, with emphasis on poisoning feral pigs. Ecological Modelling 62, 311-327.

Hone, J., 1994. Analysis of vertebrate pest control. Cambridge University Press, Cambridge, United Kingdom.

Hone, J., 1995. Spatial and temporal aspects of vertebrate pest damage with emphasis on feral pigs. Journal of Applied Ecology 32, 311-319.

Hone, J., Atkinson, B., 1983. Evaluation of fencing to control feral pig movement. Australian Wildlife Research 10, 499-505.

Hone, J., Bryant, H., Nicholls, P., Atkinson, W., Kleba, R., 1985. The acceptance of dyed grain by feral pigs and birds III. Comparison of intakes of dyed and undyed grain by feral pigs and birds in pig-proof paddocks. Australian Wildlife Research 12, $447-454$

Hone, J., Kleba, R., 1984. The toxicity and acceptability of warfarin and 1080 poison to penned feral pigs. Australian Wildlife Research 11, 103-111.

Hone, J., Pedersen, H., 1980. Changes in a feral pig population after poisoning. In: Proceedings of the Vertebrate Pest Conference, 9. pp. 176-182.

Howe, T.D., Singer, F.J., Ackerman, B.B., 1981. Forage relationships of European wild boar invading northern hardwood forest. Journal of Wildlife Management 45 748-754.

Ickes, K., DeWalt, S.J., Appanah, S., 2001. Effects of native pigs (Sus scrofa) on woody understory vegetation in a Malaysian lowland rain forest. Journal of Tropical Ecology 17, 191-206.

Ickes, K., DeWalt, S.J., Thomas, S.C., 2003. Resprouting of woody saplings following stem snap by wild pigs in a Malaysian rain forest. Journal of Ecology 91, 222-

Ickes, K., Paciorek, C.J., Thomas, S.C., 2005. Impacts of nest construction by native pigs (Sus scrofa) on lowland Malaysian rain forest saplings. Ecology 86, 15401547.

Izac, A.-M.N., O’Brien, P., 1991. Conflict, uncertainty and risk in feral pig management: the Australian approach. Journal of Environmental Management 32, 118.

Kaller, M.D., Kelso, W.E., 2006. Swine activity alters invertebrate and microbial communities in a Coastal Plain watershed. American Midland Naturalist 156, $163-177$.

Katahira, L.K., Finnegan, P., Stone, C.P., 1993. Eradicating feral pigs in montane mesic habitat at Hawaii Volcanoes National Park. Wildlife Society Bulletin 21, 269274

Kavanaugh, D.M., Linhart, S.B., 2000. A modified bait for oral delivery of biological agents to raccoons and feral swine. Journal of Wildlife Diseases 36, 86-91.

Killian, G., Miller, L., Rhyan, J., Doten, H., 2006. Immunocontraception of Florida feral swine with a single-dose GnRH vaccine. American Journal of Reproductive Immunology 55, 378-384.

Kleba, R., Hone, J., Robards, G., 1985. The acceptance of dyed grain by feral pigs and birds II. Penned feral pigs. Australian Wildlife Research 12, 51-55

Knowlton, J.L., Donlan, C.J., Roemer, G.W., Samaniego-Herrera, A., Keitt, B.S., Wood, B., Aguirre-Muñoz, A., Kaulkner, K.R., Tershy, B.R., 2007. Eradication of nonnative mammals and the status of insular mammals on the California Channel Islands, USA, and Pacific Baja California Peninsula Islands, Mexico. Southwestern Naturalist 52, 528-540.

Kuiters, A.T., Slim, P.A., 2002. Regeneration of mixed deciduous forest in a Dutch forest-heathland, following a reduction of ungulate densities. Biological Conservation $105,65-74$

Lacki, M.J., Lancia, R.A., 1986. Effects of wild pigs on beech growth in Great Smoky Mountains National Park. Journal of Wildlife Management 50, 655-659.

Lavoie, C., Donlan, C.J., Campbell, K., Cruz, F., Carrion, G.V., 2007. Geographic tools for eradication programs of insular non-native mammals. Biological Conservation 9, 139-148.

Lipscomb, D.J., 1989. Impacts of feral hogs on longleaf pine regeneration. Southern Journal of Applied Forestry 13, 177-181.

Littauer, G.A., 1993. Control techniques for feral hogs. In: Hanselka, C.W., Cadenhead, J.F. (Eds.), Feral Swine: A Compendium for Resource Managers. Texas Agricultural Extension Service, Kerrville, TX, USA, pp. 139-148.

Lucas, E.G., 1977. Feral hogs: problems and control on National Forest lands. In: Wood, G.W. (Ed.), Research and Management of Wild Hog Populations: Proceedings of a Symposium. Belle W. Baruch Forest Science Institute, Clemson University, Clemson, South Carolina, USA, pp. 17-22.

Maillard, D., Fournier, P., 1995. Effects of shooting with hounds on size of resting range of wild boar (Sus scrofa) groups in Mediterranean habitat. IBEX Journal of Mountain Ecology 3, 102-107.

Mansfield, T.M., 1978. Wild pig management on a California public hunting area. Transactions of the Western Section of The Wildlife Society 14, 187-201.

Mapston, M.E., 1999. Feral hog control methods. In: Proceedings of the National Feral Swine Conference, 1. pp. 117-120.

Mapston, M.E., 2004. Feral hogs in Texas. Texas Cooperative Extension, Publication B-6149, College Station, TX, USA.

Matschke, G.H., 1962. Trapping and handling European wild hogs. In: Proceedings of the Southeastern Association of Fish and Wildlife Agencies, 16. pp. 21 24. 
Mayer, J.J., Nelson, E.A., Wike, L.D., 2000. Selective depredation of planted hardwood seedlings by wild pigs in a wetland restoration area. Ecological Engineering 15 S79-S85.

Mazzoni della Stella, R., Calovi, F., Burrini, L., 1995. The wild boar management in a province of the central Italy. IBEX Journal of Mountain Ecology 3, 213-216.

McIlroy, J.C., 1983. The sensitivity of Australian animals to 1080 poison V. The sensitivity of feral pigs, Sus scrofa, to 1080 and its implications for poisoning campaigns. Australian Wildlife Research 10, 139-148.

McIlroy, J.C., 1992. The effect on Australian animals of 1080-poisoning campaigns. In: Proceedings of the Vertebrate Pest Conference, 15. pp. 356-359.

McIlroy, J.C., 1995. New techniques for an old problem-recent advances in feral pig control in Australia. IBEX Journal of Mountain Ecology 3, 241-244.

McIlroy, J.C., Braysher, M., Saunders, G.R., 1989. Effectiveness of a warfarin-poisoning campaign against feral pigs, Sus scrofa, in Namadgi National Park, A.C.T. Australian Wildlife Research 16, 195-202.

McIlroy, J.C., Gifford, E.J., 1997. The 'Judas' pig technique: a method that could enhance control programmes against feral pigs, Sus scrofa. Wildlife Research 24, 483-491.

McIlroy, J.C., Gifford, E.J., 2005. Are oestrous feral pigs, Sus scrofa, useful as trapping lures? Wildlife Research 32, 605-608.

McIlroy, J.C., Gifford, E.J., Forrester, R.I., 1993. Seasonal patterns in bait consumption by feral pigs (Sus scrofa) in the hill country of south-eastern Australia. Wildlife Research 20, 637-651.

McIlroy, J.C., Saillard, R.J., 1989. The effect of hunting with dogs on the numbers and movements of feral pigs, Sus scrofa, and the subsequent success of poisoning exercises in Namadgi National Park, A.C.T. Australian Wildlife Research 16, 353-363.

Miller, L.A., Talwar, G.P., Killian, G.J., 2006. Contraceptive effect of a recombinant GnRH vaccine in adult female pigs. In: Proceedings of the Vertebrate Pest Conference, 22. pp. 106-109.

Mitchell, J., 1998. The effectiveness of aerial baiting for control of feral pigs (Sus scrofa) in North Queensland. Wildlife Research 25, 297-303.

Mitchell, J., Dorney, W., Mayer, R., Mcllroy, J., 2007. Ecological impacts of feral pig digging in north Queensland rainforests. Wildlife Research 34, 603-608

Mohr, D., Cohnstaedt, L.D., Topp, W., 2005. Wild boar and red deer affect soil nutrients and soil biota in steep oak stands of the Eifel. Soil Biology \& Biochemistry $37,693-700$

O'Brien, P.H., 1988. The toxicity of sodium monofluoroacetate (compound 1080) to captive feral pigs, Sus scrofa. Australian Wildlife Research 15, 163-170.

O'Brien, P.H., Kleba, R.E., Beck, J.A., Baker, P.J., 1986. Vomiting by feral pigs after 1080 intoxication: nontarget hazard and influence of anti-emetics. Wildlife Society Bulletin 14, 425-432.

O'Brien, P.H., Lukins, B.S., 1988. Factors influencing the intake of sodium monofluoroacetate (compound 1080) by free-ranging feral pigs. Australian Wildlife Research 15, 285-291.

O'Brien, P.H., Lukins, B.S., 1990. Comparative dose-response relationships and acceptability of warfarin, brodifacoum and phosphorus to feral pigs. Australian Wildlife Research 17, 101-112.

O'Brien, P.H., Lukins, B.S., Beck, J.A., 1988. Bait type influences the toxicity of sodium monofluoouroacetate (compound 1080 ) to feral pigs. Australian Wildlife Research 15, 451-457.

Pavlov, P.M., Hone, J., Kilgour, R.J., Pedersen, H., 1981. Predation by feral pigs on Merino lambs at Nyngan, New South Wales. Australian Journal of Experimental Agriculture 21, 570-574.

Peine, J.D., Farmer, J.A., 1990. Wild hog management program at Great Smoky Mountains National Park. In: Proceedings of the Vertebrate Pest Conference, 14. pp. 221-227.

Peters, H.A., 2001. Clidemia hirta invasion at the Pasoh Forest Reserve: an unexpected plant invasion in an undisturbed tropical forest. Biotropica 33, 60-68.

Pimentel, D., Zuniga, R., Morrison, D., 2005. Update on the environmental and economic coasts associate with alien-invasive species in the United States. Ecological Economics 52, 273-288.

Ralph, C.J., Maxwell, B.D., 1984. Relative effects of human and feral hog disturbance on a wet forest in Hawaii. Biological Conservation 30, 291-303.

Rathore, A.K., 1985. Use of metoclopramide to prevent 1080 -induced emesis in wild pigs. Journal of Wildlife Management 49, 55-56.

Reidy, M.M., Campbell, T.A., Hewitt, D.G., 2008. Evaluation of electric fencing to inhibit feral pig movements. Journal of Wildlife Management 72, 1012-1018.

Richardson, C.D., Gipson, P.S., Jones, D.P., Luchsinger, J.C., 1997. Extirpation of a recently established feral pig population in Kansas. In: Proceedings of the Eastern Wildlife Damage Management Conference, 7. pp. 100-103.

Robinson, C.J., Smyth, D., Whitehead, P.J., 2005. Bush tucker, bush pets, and bush threats: cooperative management of feral animals in Australia's Kakadu National Park. Conservation Biology 19, 1385-1391.

Roemer, G.W., Coonan, T.J., Garcelon, D.K., Bascompte, J., Laughrin, L., 2001. Feral pigs facilitate hyperpredation by golden eagles and indirectly cause the decline of the island fox. Animal Conservation 4, 307-318.

Roemer, G.W., Donlan, C.J., Courchamp, F., 2002. Golden eagles, feral pigs, and insular carnivores: how exotic species turn native predators into prey. In: Proceedings of the National Academy of Sciences, 99. pp. 791-796.

Rollins, D., 1993. Statewide attitude survey on feral hogs in Texas. In: Hanselka, C.W., Cadenhead, J.F. (Eds.), Feral Swine: A Compendium for Resource Managers. Texas Agricultural Extension Service, Kerrville, TX, USA, pp. 1-8.

Rollins, D., Carroll, J.P., 2001. Impacts of predation on northern bobwhite and scaled quail. Wildlife Society Bulletin 29, 39-51.
Rollins, D., Higginbotham, B.J., Cearley, K.A., Wilkins, R.N., 2007. Appreciating feral hogs: extension education for diverse stakeholders in Texas. Human-Wildlife Conflicts 1, 192-198.

Saunders, G., 1993. Observations on the effectiveness of shooting feral pigs from helicopters. Wildlife Research 20, 771-776.

Saunders, G., Bryant, H., 1988. The evaluation of a feral pig eradication program during a simulated exotic disease outbreak. Australian Wildlife Research 15 $73-81$.

Saunders, G., Kay, B., Nicol, H., 1993. Factors affecting bait uptake and trapping success for feral pigs (Sus scrofa) in Kosciusko National Park. Wildlife Research 20, 653-665.

Saunders, G., Kay, B., Parker, B., 1990. Evaluation of a warfarin poisoning programme for feral pigs (Sus scrofa). Australian Wildlife Research 17, 525-533.

Schaefer, T., 2004. Video monitoring of shrub-nests reveals nest predators. Bird Study $51,170-177$

Seward, N.W., VerCauteren, K.C., Witmer, G.W., Engeman, R.M., 2004. Feral swine impacts on agriculture and the environment. Sheep and Goat Research Journal $19,34-40$.

Sierra, C., 2001. El cerdo cimarrón (Sus scrofa, Suidae) en la Isla del Coco, Costa Rica: escarbaduras, alteraciones al suelo y erosión. Revista de Biología Tropical 49, 1158-1170.

Singer, F.J., Swank, W.T., Clebsch, E.E.C., 1984. Effects of wild pig rooting in a deciduous forest. Journal of Wildlife Management 48, 464-473.

Sodeikat, G., Pohlmeyer, K., 2003. Escape movements of family groups of wild boar Sus scrofa influenced by drive hunts in Lower Saxony, Germany. Wildlife Biology 9 (Suppl. 1), 43-49.

Sowls, L.K., 1997. Javelinas and Other Peccaries: Their Biology, Management, and Use, second edition. Texas A\&M University Press, College Station, TX, USA

State of Hawaii, 2007. Review of methods and approach for control of non-native ungulates in Hawaii. Department of Land and Natural Resources, Division of Forestry and Wildlife, Technical Report 07-01, Honolulu, Hawaii, USA.

Sterner, J.D., Barrett, R.H., 1991. Removing feral pigs from Santa Cruz Island, California. Transactions of the Western Section of The Wildlife Society 27, 47-53.

Stevens, R.L., 1996. The Feral Hog in Oklahoma. Samuel Roberts Noble Foundation, Ardmore, OK, USA

Sweeney, J.R., Sweeney, J.M., Sweeney, S.W., 2003. Feral hog. In: Feldhamer, G.A (Ed.), Chapman, J.A. (Eds.), Wild Mammals of North America: Biology, Management, and Conservation. second edition. John Hopkins University Press, Baltimore, MD, USA, pp. 1164-1179.

Sweitzer, R.A., Gonzales, B.J., Gardner, I.A., Van Vuren, D., Waithman, J.D., Boyce, W.M., 1997. A modified panel trap and immobilization technique for capturing multiple wild pigs. Wildlife Society Bulletin 25, 699-705.

Sweitzer, R.A., Van Vuren, D.H., 2002. Rooting and foraging effects of wild pigs on tree regeneration and acorn survival in California's oak woodland ecosystems. United States Forest Service General Technical Report PSW-GTR-184, Washington, DC, USA.

Taylor, R., 2003. The Feral Hog in Texas. Texas Parks and Wildlife PWD BK W7000195, Austin, TX, USA

Tisdell, C.A., 1980. Wild Pigs: Environmental Pest or Economic Resource? Pergamon Press, New York, NY, USA.

Twigg, L.E., Lowe, T., Everett, M., Martin, G., 2006. Feral pigs in north-western Australia: population recovery after 1080 baiting and further control. Wildlife Research 33, 417-425.

Twigg, L.E., Lowe, T., Martin, G., 2005a. Sodium fluoroacetate residues and carcass degradation of free-ranging feral pigs poisoned with 1080. Wildlife Research 32 , 573-580.

Twigg, L.E., Lowe, T., Martin, G., 2007. Bait consumption by, and 1080-based control of, feral pigs in the Mediterranean climatic region of south-western Australia. Wildlife Research 34, 125-139.

Twigg, L.E., Lowe, T., Martin, G., Everett, M., 2005b. Feral pigs in north-western Australia: basic biology, bait consumption, and the efficacy of 1080 baits. Wildlife Research 32, 281-296.

Updike, D., Waithman, J., 1996. Dealing with wild pig depredation in California: the strategic plan. In: Proceedings of the Vertebrate Pest Conference, 17. pp. 40-43.

Van Wieren, S.E., Worm, P.B., 2001. The use of a motorway wildlife overpass by large mammals. Netherlands Journal of Zoology 51, 97-105.

VerCauteren, K.C., Dolbeer, R.A., Gese, E.M., 2005. Identification and management of wildlife damage. In: Braun, C.E. (Ed.), Techniques for Wildlife Investigations and Management. sixth edition. The Wildlife Society, Bethesda, MD, USA, pp. 740778 .

Vtorov, I.P., 1993. Feral pig removal: effects on soil microarthropods in a Hawaiian ran forest. Journal of Wildlife Management 57, 875-878.

Wakely, P.C., 1954. Planting the southern pine. United States Forest Service, Agricultural Monograph 18, Washington, DC, USA.

Wilcox, J.T., Aschehoug, E.T., Scott, C.A., Van Vuren, D.H., 2004. A test of the Judas technique as a method for eradicating feral pigs. Transactions of the Western Section of The Wildlife Society 40, 120-126.

Wyckoff, A.C., Henke, S.E., Campbell, T.A., VerCauteren, K.C., 2006. Is trapping success of feral hogs dependent upon weather conditions? In: Proceedings of the Vertebrate Pest Conference, 22. pp. 370-372.

Zivin, J., Hueth, B.M., Zilberman, D., 2000. Managing a multiple-use resource: the case of feral pig management in California rangeland. Journal of Environmental Economics and Management 39, 189-204. 